\title{
Early Undifferentiated Spondyloarthropathy in a Patient with Sarcoidosis
}

\author{
Sarkoidozlu Bir Hastada Erken Diferansiye Olmamış Spondiloartropati
}

\author{
Murat KARA, ${ }^{1}$ Levent ÖZÇAKAR, ${ }^{2}$ Fuat KALYONCU, ${ }^{3}$ Ayşen AKINCI ${ }^{2}$ \\ ${ }^{1}$ Department of Physical Medicine and Rehabilitation, \\ Ankara Physical Medicine and Rehabilitation Education and Research Hospital, Ankara, Turkey \\ ${ }^{2}$ Department of Physical Medicine and Rehabilitation, Medical Faculty of Hacettepe University, Ankara, Turkey \\ ${ }^{3}$ Department of Chest Disease and Allergy, Medical Faculty of Hacettepe University, Ankara, Turkey
}

In this article, we present a 49-year-old male case who was admitted with inflammatory back pain and uveitis when he was in remission for sarcoidosis. The concomitance of undifferentiated spondyloarthropathy and sarcoidosis with an emphasis on their possible etiological association was also discussed in the light of current diagnostic and therapeutic challenges.

Key words: Inflammatory back pain; sarcoidosis; spondyloarthropathy; uveitis.

Sarcoidosis is an inflammatory, multi-system disorder of unknown origin that is characterized by the presence of non-caseating granulomata. ${ }^{[1]}$ It usually affects young adults, and the clinical scenario presents as bilateral hilar lymphadenopathy, pulmonary infiltrates, and, less frequently, skin, ocular, and joint manifestations. ${ }^{[2]}$ In most cases, arthritis occurs as a part of Löfgren's syndrome, which is characterized by bilateral hilar lymphadenopathy and erythema nodosum. In cases in which inflammatory back pain and uveitis ensue, the disease may also mimic a form of spondyloarthropathy (SpA). Herein, we report a rare case of undifferentiated $\mathrm{SpA}(\mathrm{uSpA})$ presenting in conjunction with anterior uveitis in a patient with Löfgren's syndrome during remission (while taking no medication).
$\mathrm{Bu}$ yazıda, sarkoidoz remisyonunda iken inflamatuvar bel ağrısı ve üveit ile başvuran 49 yaşında bir erkek olgu sunuldu. Diferansiye olmamış spondiloartropati ve sarkoidoz birlikteliği, muhtemel etyolojik ilişki göz önünde bulundurularak, tanı ve tedavideki mevcut zorluklar eşliğinde irdelendi.

Anahtar sözcükler: İnflamatuvar bel ağrısı; sarkoidoz; spondiloartropati; üveit.

\section{CASE REPORT}

A 49-year-old man was admitted to our facility with mild but continuous inflammatory low back and alternating buttocks pain that had been occurring for the previous five years. In addition, the patient stated that he had also been suffering from morning stiffness, but this did not exceed a one-hour period. His complaints responded to nonsteroidal antiinflammatory drugs (NSAIDS), and his condition improved with exercise. Two months prior to coming to our facility, the patient visited an ophthalmologist due to progressive visual impairment and was diagnosed as having low grade bilateral uveitis that responded to local corticosteroid therapy. His medical history revealed Löfgren's syndrome, a single episode 
of arthralgia, erythema nodosum, and bilateral hilar lymphadenopathy that had been ongoing for the past 20 years. He had been treated with a six month corticosteroid therapy and had also been prescribed statins periodically for hyperlipidemia over the previous eight years.

Physical examination revealed low back pain and stiffness, but an evaluation of the sacroiliac and peripheral joints was normal. The modified lumbar Schober's test yielded a result of $5 \mathrm{~cm}$, and chest expansion during maximum inspiration was $1 \mathrm{~cm}$. Systemic examination was unremarkable. The patient's laboratory tests, including complete blood count (CBC), liver and renal function tests, erythrocyte sedimentation rate (ESR), C-reactive protein (CRP), and rheumatoid factor (RF), were normal, but he tested negative for the human leukocyte antigen (HLA)-B27. The magnetic resonance imaging (MRI) results of the sacroiliac joints were also normal. After examining all of the data, the patient was diagnosed as having early uSpA.

\section{DISCUSSION}

Spondyloarthropathies are a group of diseases that present primarily with inflammation of the axial skeleton, peripheral arthritis, enthesitis, morning stiffness, dactylitis, and acute anterior uveitis. Additionally, it is well known that there is a correlation between the HLA-B27 antigen and family aggregation. Patients with inflammatory low back pain who do not yet fulfill the modified New York criteria for ankylosing spondylitis (AS) are classified as $\mathrm{uSpA},{ }^{[3]}$ and more than half of the patients with uSpA develop AS over time. ${ }^{[4]}$

On the other hand, SpA and sarcoidosis are two distinct entities which have no shared predisposing genetic factors. Each of them is associated with different major histocompatibility (MHC) antigens. Ankylosing spondylitis is strongly related to the class I MHC antigen HLA B27, but sarcoidosis is related to the MHC II-coded alleles. Nevertheless, there are higher numbers of $\mathrm{CD} 4+\mathrm{T}$ cells in both diseases. ${ }^{[5]}$ Furthermore, bacterial or viral infections are suspected as being contributors to the immunemediated inflammation in both SpA and sarcoidosis. Moreover, monoclonal antibodies to gram-negative bacteria can cross-react with HLA-B27 in SpA ${ }^{[6]}$ while mycobacterial infection could possibly be related to sarcoidosis. ${ }^{[7]}$ Although various viral and bacterial agents have been reported, some agents, for example propriobacterium acnes, have been isolated from tissues in both diseases. ${ }^{[5]}$

Acute anterior uveitis is the most frequent extraarticular manifestation in patients with $\mathrm{AS},{ }^{[8]}$ and this can be the initial symptom of SpA, especially if the patients have been diagnosed with uSpA. ${ }^{[9,10]}$ Similar to our case, a study by Fernández-Melón et al. ${ }^{[9]}$ determined that uveitis was the first clinical sign to prompt diagnosis in $41 \%$ of the patients with SpA. Furthermore, in a systematic analysis by Zeboulon et al., ${ }^{[1]}$ the prevalence of uveitis in SpA was 32.7\%, and this percentage increased with longer disease duration. In a retrospective study of patients presenting with various uveitis subtypes, Chan et al. ${ }^{[12]}$ found that anterior uveitis was diagnosed in half of the subjects, with the most common diagnoses being HLA-B27-associated diseases (20.8\%), AS (9.6\%), herpes infections (7.6\%), and sarcoidosis (6.2\%). In addition, a negative test for HLA-B27 was a prognostic factor for the presence of anterior uveitis and axial involvement in several follow-up reports that focused on AS patients. ${ }^{[13-15]}$ Zeboulon et al. ${ }^{[11]}$ also reported that the prevalence of uveitis ranged from $40-48 \%$ in patients with HLA-B27-positive SpA but only 15-25\% in HLAB27-negative patients. Although the possibility of sarcoidosis-related uveitis can not be ruled out in our case, we considered the diagnosis of uSpA to be more likely due to the patient's rapid recovery from non-granulomatous eye lesions combined with his inflammatory low back pain.

The presence of concomitant SpA and sarcoidosis has rarely been reported. ${ }^{[16-18]}$ In addition, there have been recent reports concerning patients with quiescent sarcoidosis who relapsed after treatment with tumor necrosis factor-alpha (TNF- $\alpha$ ) inhibitors for SpA. ${ }^{[19-22]}$ Therefore, a relevant association between these two disorders or their coexistence may cause diagnostic and/or therapeutic challenges. In this regard, we believe that the development of inflammatory back pain (with or without uveitis) in sarcoidosis patients should alert physicians to the fact that more than one form of spondyloarthropathy is possible and that these patients have to be followed up with close observation for prompt management.

\section{Declaration of conflicting interests}

The authors declared no conflicts of interest with respect to the authorship and/or publication of this article. 


\section{Funding}

The authors received no financial support for the research and/or authorship of this article.

\section{REFERENCES}

1. Newman LS, Rose CS, Maier LA. Sarcoidosis. N Engl J Med 1997;336:1224-34.

2. McCoy RC, Tisher CC. Glomerulonephritis associated with sarcoidosis. Am J Pathol 1972;68:339-58.

3. van der Linden S, Valkenburg HA, Cats A. Evaluation of diagnostic criteria for ankylosing spondylitis. A proposal for modification of the New York criteria. Arthritis Rheum 1984;27:361-8.

4. Mau W, Zeidler H, Mau R, Majewski A, Freyschmidt J, Stangel W, et al. Clinical features and prognosis of patients with possible ankylosing spondylitis. Results of a 10-year followup. J Rheumatol 1988;15:1109-14.

5. Sezer I, Melikoglu MA, Cay HF, Kocabas H, Kacar C. A co-occurrence of sarcoidosis and ankylosing spondylitis: a case report. Rheumatol Int 2008;28:605-7.

6. Raybourne RB, Bunning VK, Williams KM. Reaction of anti-HLA-B monoclonal antibodies with envelope proteins of Shigella species. Evidence for molecular mimicry in the spondyloarthropathies. J Immunol 1988;140:3489-95.

7. Gupta D, Agarwal R, Aggarwal AN, Jindal SK. Molecular evidence for the role of mycobacteria in sarcoidosis: a meta-analysis. Eur Respir J 2007;30:508-16.

8. Khan MA. Ankylosing spondylitis: clinical aspects. In: Calin A, Taurog JD, editors. The spondylarthritides. Oxford: Oxford University Press; 1998. p. 27-40.

9. Fernández-Melón J, Muñoz-Fernández S, Hidalgo V, Bonilla-Hernán G, Schlincker A, Fonseca A, et al. Uveitis as the initial clinical manifestation in patients with spondyloarthropathies. J Rheumatol 2004;31:524-7.

10. Linder R, Hoffmann A, Brunner R. Prevalence of the spondyloarthritides in patients with uveitis. J Rheumatol 2004;31:2226-9.
11. Zeboulon N, Dougados M, Gossec L. Prevalence and characteristics of uveitis in the spondyloarthropathies: a systematic literature review. Ann Rheum Dis 2008;67:955-9.

12. Chan SM, Hudson M, Weis E. Anterior and intermediate uveitis cases referred to a tertiary centre in Alberta. Can J Ophthalmol 2007;42:860-4.

13. Paiva ES, Macaluso DC, Edwards A, Rosenbaum JT. Characterisation of uveitis in patients with psoriatic arthritis. Ann Rheum Dis 2000;59:67-70.

14. Queiro R, Torre JC, Belzunegui J, González C, De Dios JR, Unanue $\mathrm{F}$, et al. Clinical features and predictive factors in psoriatic arthritis-related uveitis. Semin Arthritis Rheum 2002;31:264-70.

15. Durrani K, Foster CS. Psoriatic uveitis: a distinct clinical entity? Am J Ophthalmol 2005;139:106-11.

16. Gómez-Puerta JA, Musuruana J, Saez C, Cervera R, Font J. Sarcoidosis as seronegative spondyloarthropathy. Biomedica 2005;25:435-8. [Abstract]

17. Kötter I, Dürk H, Saal JG. Sacroiliitis in sarcoidosis: case reports and review of the literature. Clin Rheumatol 1995;14:695-700.

18. Abouzahir A, El Maghraoui A, Tabache F, Bezza A, Chaari J, Ghafir D, et al. Sarcoidosis and ankylosing spondylitis. A case report and review of the literature. Ann Med Interne (Paris) 2002;153:407-10. [Abstract]

19. González-López MA, Blanco R, González-Vela MC, Fernández-Llaca H, Rodríguez-Valverde V. Development of sarcoidosis during etanercept therapy. Arthritis Rheum 2006;55:817-20.

20. Phillips K, Weinblatt M. Granulomatous lung disease occurring during etanercept treatment. Arthritis Rheum 2005;53:618-20.

21. Oh J, Arkfeld DG, Horwitz DA. Development of Crohn's disease in a patient taking etanercept. J Rheumatol 2005;32:752-3.

22. Almodóvar $\mathrm{R}$, Izquierdo $\mathrm{M}$, Zarco $\mathrm{P}$, Javier Quirós F, Mazzucchelli R, Steen B. Pulmonary sarcoidosis in a patient with ankylosing spondylitis treated with infliximab. Clin Exp Rheumatol 2007;25:99-101. 